\title{
PENGARUH PERFORMANCE EXPECTANCY, EFFORT EXPECTANCY, SOCIAL INFLUENCE DAN TRUST TERHADAP NIAT BERKELANJUTAN MENGGUNAKAN FDAS PADA MASA PANDEMI COVID-19
}

\author{
Maria Augustin Lopes Amaral $\left(^{1)}\right.$ dan Engelbertus G. Ch. Watu $\left(^{2)}\right.$ \\ ${ }^{1,2}$ Manajemen, Universitas Katolik Widya Mandira Kupang \\ 1,2 Jl. Jend. Achmad Yani 50-52, Kupang, Kode Pos 85111 \\ E-mail: maria_amaral@unwira.ac.id ${ }^{1)}$ engelwatu@unwira.ac.id ${ }^{2)}$
}

\begin{abstract}
ABSTRAK
Aplikasi pengiriman makanan menjadi teknologi seluler yang sedang berkembang, dan diadopsi secara luas oleh bisnis katering dan pelanggan. Pada masa Covid-19 FDA memberikan manfaat serta menyelamatkan berbagai pihak antara lain, perusahaan di bidang makanan serta pelanggan yang bisa memanfaatkan jejaring online yang ada pada FDA. Artikel ini bertujuan untuk mengidentifikasi implikasi pengaruh 4 faktor yaitu performance expectancy, effort expectancy, social influence dan trust terhadap continuance intention of using FDAs. Sampel dalam penelitian ini berjumlah 120 orang yang pernah menggunakan aplikasi pengiriman makanan setidaknya sekali dengan menggunakan metode convenience sampling. Hasil yang diolah dengan SEM AMOS versi 24 menunjukkan bahwa faktor yang signifikan terhadap continuance intention of using FDAs selama pandemi COVID-19 adalah performance expectancy, effort expectancy, dan social influence. Yang tidak berpengaruh adalah faktor trust.
\end{abstract}

Kata kunci: Performance Expectancy, Effort Expectancy, Social Influence, Trust, Fdas

\section{PENDAHULUAN}

Perangkat seluler telah diadopsi secara luas dalam kehidupan, sehingga penggunaannya meningkat tajam di seluruh dunia. Menurut laporan dari Keminfo, di tahun 2020 ada sekitar $89 \%$ orang Indonesia yang menggunakan telepon seluler untuk berbagai aktivitas di masa pandemik covid-19 (www.mediaindonesia.com). Sementara itu, berbagai layanan seluler secara signifikan dikembangkan dan diimplementasikan di berbagai industri. Aplikasi pengiriman makanan (FDA) sebagai layanan seluler online ke offline baru-baru ini mendapatkan popularitas yang menawarkan manfaat dua arah bagi perusahaan makanan dan pelanggan dengan menyediakan pesanan online dan layanan pengiriman offline yang nyaman dan efisien. Statistic Reports (2020) menggambarkan bahwa pengguna internet di Indonesia memakai aplikasi FDA sebanyak 74,4\%.

Sementara itu, novel corona virus 2019 (COVID2019) meletus sebagai pandemi global yang serius sejak akhir 2019 dan mencapai seluruh China pada Februari 2020, kemudian secara progresif meluas ke seluruh dunia (Tang dkk., 2020). Menurut laporan dari Organisasi Kesehatan Dunia (WHO), hingga 21 Mei 2020, ada total 4.904.413 kasus infeksi COVID-19 yang dikonfirmasi secara global dan 323.412 kematian (WHO, 2020a). Selama krisis COVID-19, penggunaan masker di tempat umum, social distancing, isolasi mandiri dan tindakan perlindungan diri lainnya sangat dianjurkan oleh WHO (2020) untuk menghindari kontak langsung dan tidak langsung antar manusia untuk mengurangi risiko COVID-19 transmisi (Smith and Freedman, 2020). Apalagi, karena semakin sedikit pelanggan yang berniat menggunakan layanan publik, industri makanan tradisional sangat menderita selama pandemi COVID-19. Oleh karena itu, selama pandemi COVID-19, mode "internet + restoran", food delivery app (FDA) tidak hanya memenuhi persyaratan perusahaan katering tetapi juga memenuhi permintaan pelanggan akan persediaan makanan yang nyaman dan efisien serta masalah keamanan pribadi (Liu and Wang, 2016).

Di sisi lain, meskipun pengaruh negatif COVID-19 secara signifikan mempengaruhi penawaran dan permintaan industri katering, hal itu telah mengubah kebiasaan konsumsi warga dan mempercepat transformasi perusahaan katering dari layanan tradisional di dalam toko menjadi online-to- offline untuk bertahan dalam situasi pandemi dan menjaga pembangunan berkelanjutan. Menurut laporan dari lembaga penelitian di Indonesia pengguna FDAs sebanyak 58\% dari jumlah penduduk di bulan Juni 2020.

Penelitian sebelumnya tentang faktor yang memotivasi pengguna untuk menggunakan FDA secara terus menerus di bawah situasi pandemi COVID-19 sangat penting bagi pemangku kepentingan terkait untuk memahami persyaratan dan harapan pelanggan. Dalam hal adopsi FDA, pelanggan mempertimbangkan harapan kinerja sebagai penentu utama untuk mengadopsi layanan yang relevan (Yeo dkk. 2017; Roh \& Park, 2019). Selain itu, kemudahan dan kualitas layanan, kenyamanan, pengaruh sosial, dan kepuasan juga merupakan anteseden yang cukup besar dari niat untuk mengadopsi FDA (Yeo dkk. 2017; Cho dkk. 2019; Ray dkk. 2019; Roh \& Park, 2019). Sementara itu, dalam hal keberlanjutan penggunaan teknologi informasi, 
ekspektasi kinerja, ekspektasi upaya, pengaruh sosial, dan kepercayaan penting untuk merumuskan niat penggunaan berkelanjutan pengguna (Gao dkk. 2015; Yuan dkk. 2016; Chopdar \& Sivakumar, 2019; Marinković dkk. 2020).

Selanjutnya, untuk mengevaluasi faktor-faktor yang mempengaruhi continuance intention of using FDAs yaitu menggunakan model Unified Theory of Use and Acceptance of Technology (UTAUT) (Chong, 2013; Marinković dkk. 2020) mereka menemukan bahwa kepercayaan juga memiliki dampak signifikan pada continuance intention of using FDAs. Namun, beberapa penelitian sebelumnya berfokus pada faktor-faktor yang mempengaruhi penggunaan berkelanjutan FDA, terutama dalam kondisi pandemi. Oleh karena itu, tujuan dari penelitian ini adalah untuk memenuhi kesenjangan faktor yang menentukan niat pengguna untuk menggunakan FDA selama periode COVID-19 secara berkelanjutan dan mendukung pemangku kepentingan terkait FDA untuk memahami persepsi dan perilaku pelanggan untuk mengembangkan strategi bisnis yang lebih efisien. Oleh karena itu, penelitian ini mencoba untuk fokus terhadap UTAUT dimana Performance expectancy, Effort expectancy, Social influence, Trust, memengaruhi niat penggunaan berkelanjutan pengguna FDA selama pandemi COVID-19.

\section{RUANG LINGKUP}

Batasan penelitian ini hanya memfokuskan pada untuk mengevaluasi faktor-faktor yang mempengaruhi continuance intention of using FDAs yaitu menggunakan model Unified Theory of Use and Acceptance of Technology (UTAUT). Variabel penelitian yaitu performance expectancy, effort expectancy, trust social influence dan continuance intention of using FDAs. Indikator dalam penelitian ini terdiri dari 19 indikator yang mengacu dari penelitian terdahulu. Populasi adalah orang-orang Indonesia yang menggunakan aplikasi FDAs. Metode sampel menggunakan convenience sampling, alat analisis menggunakan SEM AMOS versi 24.

Hasil dari penelitian ini dapat memberikan bukti empiris bahwa niat menggunakan aplikasi pengiriman makanan dipengaruhi oleh performance expectancy, effort expectancy, social influence dan trust. Jika niat penggunaan aplikasi makanan positif maka akan mendorong perilaku untuk menggunakan aplikasi tersebut. Namun jika berpengaruh negatif maka tidak ada tindakan untuk menggunakan aplikasi pengiriman makanan dengan FDAs.

\section{BAHAN DAN METODE}

Dalam penelitian ini membahas pengertian dari food delivery app serta membahas tentang teori UTAUT.

\section{Food Delivery App (FDA)}

FDA, sebagai teknologi seluler online ke offline yang sedang berkembang, menyediakan saluran antara perusahaan makanan dan pelanggan dengan mengintegrasikan pesanan online dan layanan pengiriman offline. FDA dapat dikategorikan menjadi dua pola (Ray dkk. 2019). Pertama, restoran itu sendiri, seperti KFC, Domino's dan Pizza hut dll. Kedua, platform perantara pihak ketiga, seperti gojek, grab yang lebih populer dan telah diadopsi secara luas di Indonesia (Roh and Park, 2019). Selain itu, untuk beradaptasi dan mengatasi situasi pandemi COVID-19, proses pengiriman tanpa kontak diterapkan di Indonesia, yang mengantarkan makanan ke gerbang pelanggan tanpa kontak langsung. Sementara itu, FDA juga melibatkan layanan pengiriman persediaan harian untuk pelanggan. Layanan tambahan ini memberikan manfaat multi-arah dalam menjaga jarak sosial secara efisien selama pandemi COVID-19, memperkaya jangkauan layanan dan mengurangi interval spatiotemporal dari proses penjualan dan konsumsi (Liu and Wang, 2016). Oleh karena itu, kualitas layanan FDA sangat mempengaruhi persepsi pengguna. Beberapa penelitian sebelumnya telah berfokus pada berbagai faktor yang mempengaruhi niat pengguna untuk mengadopsi FDA. (Yeo dkk.,2017) menekankan kegunaan pasca penggunaan dan motivasi kenyamanan yang dirasakan secara signifikan mempengaruhi niat perilaku pelanggan untuk mengadopsi layanan pengiriman makanan online. Selain itu, (Roh \& Park, 2019) memodifikasi TAM dengan moderator kewajiban moral dan menemukan bahwa kegunaan, kompatibilitas, norma subjektif, merupakan penentu signifikan dalam niat adopsi layanan pengiriman makanan online.

Kepuasan terkait dengan kualitas makanan dan efisiensi layanan, yang secara signifikan mempengaruhi adopsi layanan pengiriman makanan online (Israel \& Velu, 2019). Sementara itu menemukan bahwa kesesuaian pesanan, kualitas pengiriman, kualitas makanan, dan biaya adalah atribut paling signifikan yang mempengaruhi niat menggunakan layanan pengiriman makanan online , (Elvandari dkk. 2018). Selanjutnya, teori penggunaan dan gratifikasi dan memvalidasi bahwa pengalaman pelanggan, kemudahan penggunaan, dan karakteristik teknologi memiliki dampak signifikan pada niat perilaku untuk menggunakan FDA (Ray dkk., 2019). Demikian juga, Cho dkk. (2019) terkait nilai yang dirasakan multi-dimensi dengan sikap untuk menyelidiki niat kelanjutan FDA. Mereka mempresentasikan bahwa kepercayaan memiliki efek positif paling signifikan pada nilai yang dirasakan terhadap merumuskan sikap pengguna untuk terus menggunakan FDA.

Oleh karena itu, menurut penelitian sebelumnya yang relevan dan karakteristik FDA terkait dengan situasi wabah COVID-19 saat ini, penelitian ini berfokus pada faktor teknologi dan mental yang memengaruhi niat pelanggan untuk menggunakan FDA di Indonesia dengan mengintegrasikan variabel dari UTAUT, pengaruh sosial (Roh and Park, 2019) dari UTAUT. Selanjutnya, bagian berikut memperkenalkan landasan teoritis yang berkontribusi pada konseptualisasi model penelitian. 


\section{Unified theory of use and acceptance of technology (UTAUT)}

UTAUT, sebagai cerminan dari teori kognisi sosial, merupakan perluasan dari model penerimaan teknologi yang dikembangkan oleh (Venkatesh dkk. 2011) untuk memprediksi niat perilaku pengguna untuk menggunakan sistem teknologi baru. Secara khusus, model UTAUT telah dimodifikasi dengan variabel lain dan diimplementasikan secara luas pada adopsi teknologi seluler. Model UTAUT telah dibahas, ditinjau, dan digunakan dalam beberapa karya penelitian dan studi tentang banyak teknologi dalam dua gaya pengaturan penggunaan sejak diperkenalkan hingga saat ini, dan jumlah penelitian tentang model ini meningkat pesat dari hari ke hari. Dalam bagian ini, sejumlah penelitian ini telah ditinjau secara menyeluruh. Abu Shanab dan Pearson (2007) menerapkan model UTAUT untuk mempelajari faktor-faktor kunci yang mempengaruhi adopsi internet banking di Yordania. Mereka menyelidiki kesesuaian aplikasi UTAUT pada teknologi perbankan Internet. Para peneliti membuat kuesioner survei dan membagikannya kepada 940 nasabah melalui tiga bank di Yordania. Dengan menerapkan uji ANOVA, penelitian ini menemukan bahwa harapan kinerja, harapan usaha, dan pengaruh sosial memiliki pengaruh yang signifikan terhadap niat perilaku. Mereka menemukan bahwa konstruksi ini menjelaskan perbedaan dalam memprediksi niat untuk mengadopsi Internet banking. Para penulis juga menemukan bahwa gender moderasi hubungan antara tiga konstruksi yang disebutkan dan niat perilaku.

\subsection{Pengembangan Hipotesis}

Hipotesis 1 sampai hipotesis 4 memiliki penjelasan pengembangan yang menyatakan hubungan antar variabel.

\section{Performance expectancy $(\mathrm{PE})$}

Harapan kinerja (PE). Menurut UTAUT, harapan kinerja (PE) didefinisikan sebagai sejauh mana pengguna percaya bahwa menggunakan teknologi tertentu akan memfasilitasi kinerjanya dalam aktivitas tertentu(Venkatesh dkk. 2011). Dapat dilihat pada gambar 1, PE adalah prediktor yang signifikan untuk menentukan niat pengguna untuk mengadopsi teknologi baru. Secara konkret terkait dengan penelitian ini, pengguna merasakan utilitas yang lebih tinggi dari FDA, dan niat yang lebih besar untuk terus menggunakannya (Mun dkk. 2017; Yeo dkk. 2017; Roh \& Park, 2019). Sementara itu, penelitian sebelumnya telah memvalidasi bahwa PE memiliki efek positif yang signifikan terhadap kelanjutan penggunaan berbagai teknologi seluler, seperti internet seluler (Zhou, 2011), pesan dari seluler, dan aplikasi jejaring sosial (Lai and Shi, 2015), perbankan seluler (Yuan dkk. 2016) dan aplikasi belanja seluler (Chopdar and Sivakumar, 2019).
$\mathrm{H}_{1}$ : Performance expectancy berpengaruh terhadap niat berkelanjutan untuk menggunakan FDAs selama pandemi COVID-19

2. Effort expectancy $(E E)$

Effort expectancy (EE) sebagai variabel fundamental UTAUT didefinisikan sebagai tingkat kemudahan yang terkait dengan pemanfaatan teknologi tertentu oleh pengguna(Venkatesh dkk. 2011). EE secara positif memengaruhi niat penggunaan berkelanjutan pengguna untuk menggunakan aplikasi seluler (Kang, 2014; Fang \& Fang, 2016), dan juga telah dibuktikan di FDA (Ray $d k k$. 2019). Secara khusus, dalam penelitian ini, EE mengacu pada persepsi kemudahan pengguna dalam menggunakan FDA yang menghasilkan niat berkelanjutan yang lebih tinggi untuk menggunakannya selama pandemi COVID-19. Selain itu, dapat dilihat pada gambar 1, EE telah terlibat dalam penelitian sebelumnya dengan menerapkan UTAUT untuk menjelaskan kelanjutan penggunaan teknologi informasi (Venkatesh dkk. 2011). Namun, beberapa penelitian menemukan bahwa EE memiliki efek langsung yang tidak signifikan pada niat berkelanjutan dari teknologi seluler, seperti perbankan seluler (Yuan dkk. 2016) dan aplikasi belanja seluler (Chopdar and Sivakumar, 2019). Secara khusus, EE secara signifikan mempengaruhi PE niat kelanjutan pengguna menggunakan teknologi seluler.

$\mathrm{H}_{2}$ : Effort expectancy (EE) berpengaruh terhadap niat berkelanjutan untuk menggunakan FDAs selama pandemi Covid-19

3. Social Influence (SI)

Menurut UTAUT, pengaruh sosial (SI) didefinisikan sebagai tingkat di mana pengguna mendapatkan kemauan dari orang lain (misalnya keluarga, teman dan kolega) dorongan bahwa mereka harus menggunakan teknologi tertentu (Venkatesh dkk. 2011). Terkait dengan penelitian ini, SI telah di validasi secara signifikan menentukan niat pengguna untuk menggunakan layanan pengiriman online-to-offline(Roh and Park, 2019). Selain itu, dari aspek niat berkelanjutan untuk menggunakan teknologi seluler, dapat dilihat pada gambar 1, SI sebagai variabel penting dalam UTAUT memiliki dampak yang signifikan terhadap niat pengguna untuk terus menggunakan teknologi seluler (Lai and Shi, 2015). Sudut ini telah didukung dalam berbagai aspek, seperti situs jejaring sosial seluler (Zhou, 2011) aplikasi belanja (Chopdar and Sivakumar, 2019) dan sistem pembayaran seluler (Yuan dkk., 2016).

$\mathrm{H}_{3}$ : Social influence berpengaruh terhadap niat berkelanjutan untuk menggunakan FDAs selama pandemi Covid-19

\section{Trust (TR)}

Kepercayaan (TR) adalah situasi keyakinan seseorang tentang niat, dan tindakan yang akan mengikuti perilaku dan kemampuan yang sesuai (Venkatesh dkk. 2011; Gao dkk. 2015) Menurut penelitian ini yang berfokus pada niat berkelanjutan untuk menggunakan FDA selama pandemi COVID-19, 
kepercayaan dapat secara signifikan merumuskan harapan mental pengguna untuk percaya bahwa FDA dapat memberikan layanan yang andal (Cho dkk. 2019), yang berarti pengguna merasakan akumulasi yang lebih tinggi kepercayaan dari FDA, dan kemauan yang lebih tinggi untuk terus menggunakan FDA. Selain itu, kepercayaan telah di validasi sebagai variabel UTAUT tambahan, yang mewakili persepsi logam pribadi yang mencerminkan keamanan yang dirasakan pengguna terhadap ketidakpastian dan risiko, yang memiliki pengaruh signifikan dalam merumuskan niat perilaku pengguna (Shao dkk. 2019). Sementara itu, kepercayaan telah dikonfirmasi sebagai prediktor penting yang menentukan niat penggunaan berkelanjutan pengguna terhadap teknologi seluler (Zhou, 2011; Gao dkk. 2015).

H4: Trust berpengaruh terhadap niat berkelanjutan untuk menggunakan FDAs selama pandemi Covid-19

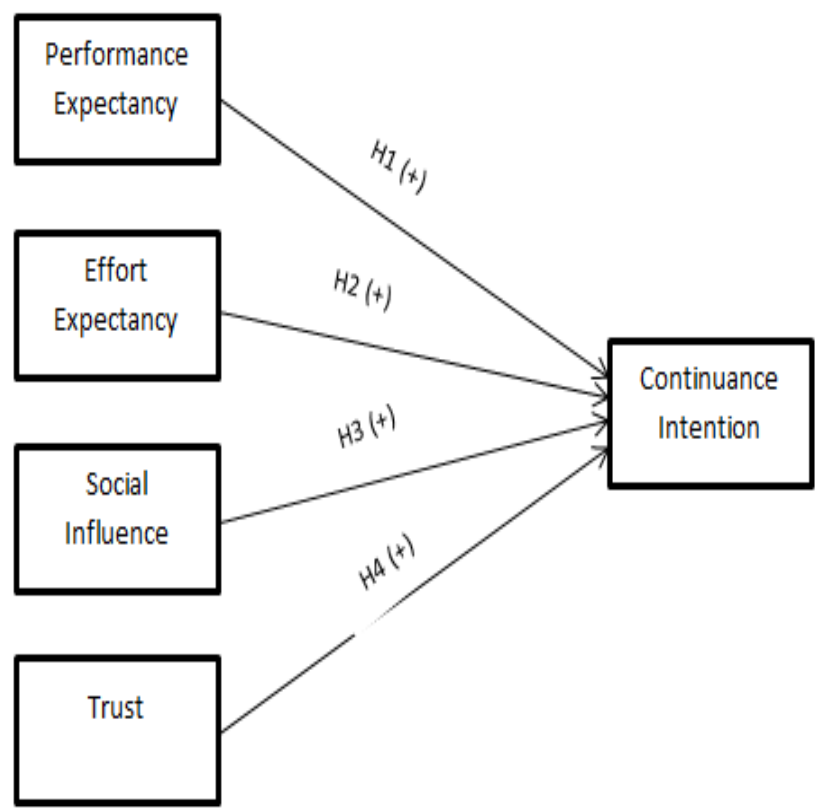

Gambar 1. Model Penelitian

\subsection{Populasi dan Sampel}

Populasi dalam penelitian ini adalah semua orang Indonesia yang menggunakan food delivery apps yaitu 202.390.000 orang (www.katadata.co.id). Metode pengambilan sample berdasarkan kenyamanan peneliti (convenience sampling). Dan sampel dalam penelitian ini menggunakan (Hair dkk. 2019) Analisis data dengan menggunakan SEM (Structural Equation Modeling) AMOS harus diatas 100 peserta atau indikator dikalikan dengan 5-10. Indikator dalam penelitian ini terdiri dari 19 indikator, sehingga sampel dipilih 120 orang dari total populasi. Jadi 19 indikator dikalikan dengan 6,3 adalah 119,7 karena jumlah kuesioner tidak ada koma maka dibulatkan menjadi 120 orang responden. (Hair dkk, 2019)

Data kuantitatif diperoleh dengan dibuat survei lapangan secara online kepada pengguna Food delivery app (FDA). Kuesioner secara terstruktur oleh responden dikembangkan sesuai dengan literatur sebelumnya dan didistribusikan sampel secara acak dan convenience sampling. Sebuah survei kuesioner diterapkan untuk mengumpulkan data untuk memvalidasi model konseptual dan menguji hipotesis penelitian. Kuesioner terdiri dari dua bagian. Bagian pertama berkonsentrasi pada informasi demografis responden yang menggunakan pertanyaan tertutup, termasuk jenis kelamin, usia, pendidikan, pekerjaan, dan frekuensi penggunaan FDA selama pandemi COVID-19. Bagian kedua terdiri dari konstruk dan item yang dirujuk dari literatur yang telah di validasi sebelumnya, terdiri dari 20 item pengukuran sebagai indikator variabel, termasuk harapan kinerja (PE), harapan upaya (EE), pengaruh sosial (SI), kepercayaan (TR) dan niat berkelanjutan (CI) menggunakan FDA, dan item skala dan referensi.

Dengan demikian, dapat dilihat pada tabel 1, semua indikator yang sesuai dengan konstruksi dalam survei diukur dengan menggunakan skala Likert tujuh poin, yang berkisar dari sangat tidak setuju $=$ "1" hingga sangat setuju $=" 7 "$. Target survei utama penelitian ini berfokus pada pengguna smartphone yang mengadopsi FDA selama periode virus COVID-19 yang sedang berlangsung di Indonesia. Data kuesioner dikumpulkan melalui survei online dan penyelidikan melalui google form selama periode 3 minggu, dari 20 Agustus 2021 hingga 11 September 2021. 
Tabel 1. Operasional Variabel

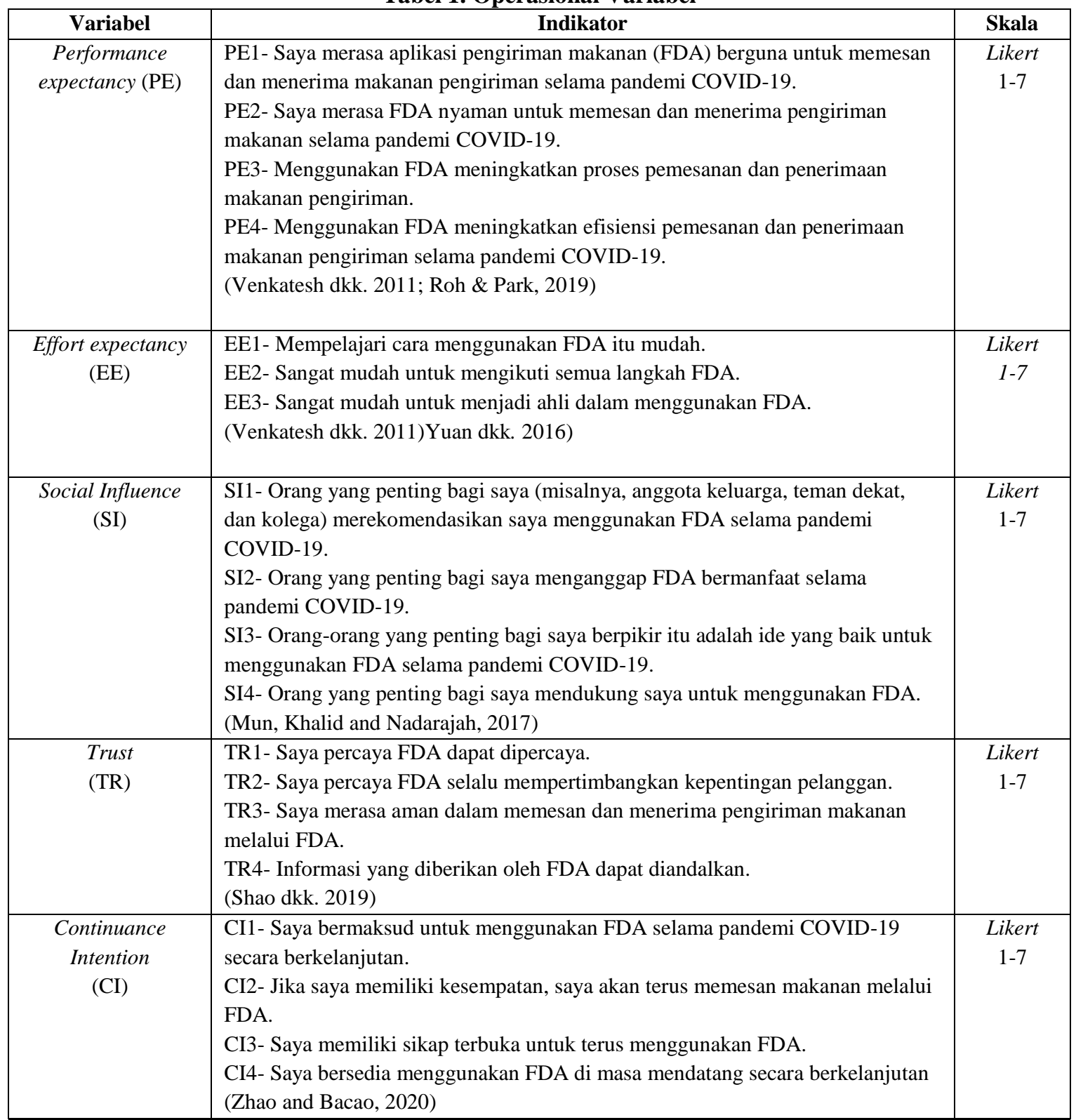

\section{PEMBAHASAN}

Hasil dari penelitian ini meliputi penjelasan karakteristik responden, uji validitas dan reliabilitas, uji hipotesis dan kecocokan antara model penelitian dengan populasi dan sampel.

\subsection{Profil Responden}

Profil responden mewakili secara keseluruhan berdasarkan jenis kelamin, usia, tingkat pendidikan terakhir dan lain sebagainya dapat dilihat pada tabel 2. 
2021, The Author(s). This is an open access article, free of all copyright, that anyone can freely read, download, copy, distribute, print, search, or link to the full texts or use them for any other lawful purpose. This article is made available under a Creative Commons Attribution 4.0 International License, which permits unrestricted use, distribution, and reproduction in any medium, provided the original work is properly cited. SEBATIK is a journal of the STMIK Widya Cipta Dharma

Tabel 2. Profil Responden

\begin{tabular}{|l|c|c|}
\hline \multicolumn{1}{|c|}{ Uraian } & Jumlah & Persentase \\
\hline Jenis Kelamin & & \\
\hline Pria & 64 & $49,2 \%$ \\
\hline Wanita & 66 & $50,8 \%$ \\
\hline Usia & & \\
\hline $21-30$ & 83 & $63,8 \%$ \\
\hline $31-40$ & 4 & $31,5 \%$ \\
\hline $41-50$ & 2 & $3,2 \%$ \\
\hline$>50$ & & $1,5 \%$ \\
\hline Pendidikan Terakhir & 46 & $35,4 \%$ \\
\hline SMA/SMK & 12 & $9,2 \%$ \\
\hline D3 & 60 & $46,2 \%$ \\
\hline S1 & 11 & $8,5 \%$ \\
\hline S2/S3 & 1 & $0,7 \%$ \\
\hline Lainnya & & \\
\hline Pekerjaan & 57 & $43,8 \%$ \\
\hline Pelajar & 10 & $7,7 \%$ \\
\hline Wiraswasta & 7 & $5,3 \%$ \\
\hline Ibu Rumah Tangga & 5 & $3,8 \%$ \\
\hline Pegawai Negeri & 40 & $31 \%$ \\
\hline Pegawai Swasta & 11 & $8,4 \%$ \\
\hline Lainnya & 26 & $20 \%$ \\
\hline Frekuensi & 52 & $40 \%$ \\
\hline Sekali dalam 3 hari & 34 & $13,8 \%$ \\
\hline 1 kali dalam 1 minggu & & \\
\hline 1 kali dalam 2 minggu & & \\
\hline 1 kali dalam 1 bulan & & \\
\hline & & \\
\hline
\end{tabular}

Distribusi sampel demografi terdiri dari $49,2 \%$ lakilaki dan 50,8\% perempuan; proporsi rentang usia adalah 21-30 dengan $63,8 \%$, ada $46,2 \%$ responden dengan gelar sarjana strata satu. Sementara pelajar dan pegawai swasta merupakan dua kelompok responden utama dengan persentase masing-masing $43,8 \%$ dan $31 \%$, dan ada $40 \%$ dari total tanggapan menggunakan FDA setidaknya sekali dalam 1 minggu.

\subsection{Uji Validitas dan Reliabilitas}

Hasil uji menggunakan alat analisis, hasil uji validitas dan reliabilitas ditampilkan pada tabel 3.
Tabel 3. Hasil Validitas dan Reliabilitas

\begin{tabular}{|c|c|c|c|}
\hline Variabel & $\begin{array}{l}\text { Factor } \\
\text { loading }\end{array}$ & AVE & CR \\
\hline $\begin{array}{c}\text { Performance } \\
\text { expectancy }\end{array}$ & & & \\
\hline PE1 & 0,876 & \multirow{4}{*}{0,555} & \multirow{4}{*}{0,825} \\
\hline PE2 & 0,916 & & \\
\hline PE3 & 0,571 & & \\
\hline PE4 & 0,535 & & \\
\hline $\begin{array}{c}\text { Effort } \\
\text { Expectancy }\end{array}$ & & & \\
\hline EE1 & 0,879 & \multirow{3}{*}{0,738} & \multirow{3}{*}{0,893} \\
\hline EE2 & 0,947 & & \\
\hline EE3 & 0,737 & & \\
\hline $\begin{array}{c}\text { Social } \\
\text { Influence }\end{array}$ & & & \\
\hline SI1 & 0,725 & \multirow{4}{*}{0,592} & \multirow{4}{*}{0,853} \\
\hline SI2 & 0,749 & & \\
\hline SI3 & 0,757 & & \\
\hline SI4 & 0,842 & & \\
\hline Trust & & & \\
\hline TR1 & 0,884 & \multirow{4}{*}{0,599} & \multirow{4}{*}{0,855} \\
\hline TR2 & 0,704 & & \\
\hline TR3 & 0,649 & & \\
\hline TR4 & 0,836 & & \\
\hline $\begin{array}{c}\text { Continuance } \\
\text { intention }\end{array}$ & & & \\
\hline CI1 & 0,895 & \multirow{4}{*}{0,708} & \multirow{4}{*}{0,906} \\
\hline CI2 & 0,891 & & \\
\hline $\mathrm{CI} 3$ & 0,849 & & \\
\hline CI4 & 0,719 & & \\
\hline
\end{tabular}

Semua indikator dalam penelitian ini valid atau dapat terukur dan reliable sesuai dengan ketentuan Hair $d k k$. (2010), dimana factor loading $\geq 0,5$, AVE $\geq 0,5$, dan $\mathrm{CR} \geq 0,7$.

\subsection{Goodness of Fit dan Uji Hipotesis}

Tabel 4 memberikan gambaran bahwa patokan goodness of fit antara lain chi square, RMSEA, CMIN/df, CFI, TLI menentukan satu ukuran dengan tolak ukur poor fit, marginal fit dan good fit. (Sarstedt dkk, 2017) bila terdapat satu ukuran yang cocok maka model dinyatakan fit. Model dalam penelitian ini dinyatakan fit. 
Tabel 4. Goodness of Fit

\begin{tabular}{|c|c|c|c|}
\hline $\begin{array}{c}\text { Uji } \\
\text { Kelayakan }\end{array}$ & Kriteria & Hasil & Keterangan \\
\hline \multicolumn{4}{|c|}{ Absolute fit measure } \\
\hline $\begin{array}{c}\text { Statistik Chi } \\
\text { Square }\end{array}$ & $\mathrm{P}>0,05$ & 1026,171 & Good fit \\
\hline RMSEA & $\leq 0,08$ & 0,223 & Poor fit \\
\hline Cmin/df & $\leq 5$ & 4,934 & Good fit \\
\hline \multicolumn{4}{|c|}{ Incremental fit measure } \\
\hline CFI & $\geq 0,90$ & 0,888 & Marginal fit \\
\hline TLI & $>0,90$ & 0,824 & Marginal fit \\
\hline
\end{tabular}

Berdasarkan hipotesis sebelumnya, model persamaan struktural dikembangkan. Di gambar 2, model persamaan struktural menghasilkan Chi-square 1026,717 dengan degree of freedom 148 (p/0,000).

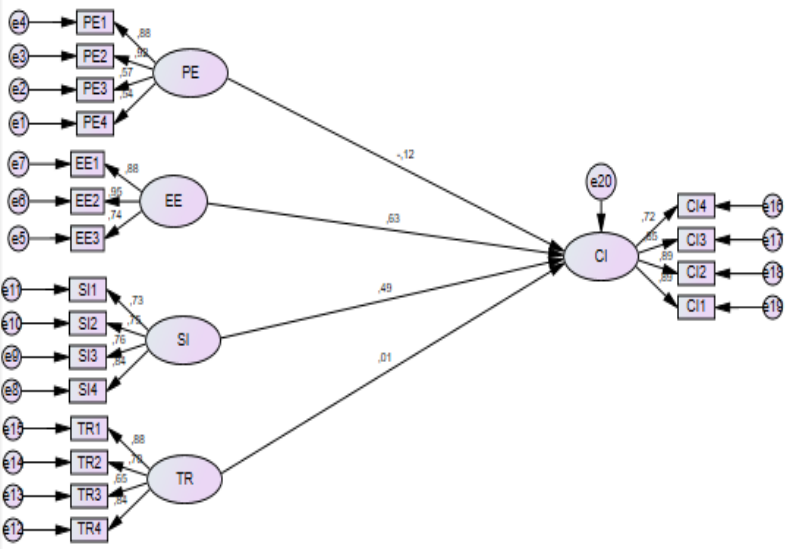

Gambar 2. Model Struktural

Dapat dilihat pada tabel 5, temuan ini menunjukkan bahwa kualitas dan kemudahan layanan FDA mempengaruhi niat berkelanjutan penggunaan FDA selama pandemi COVID-19.

Tabel 5. Ringkasan Pengujian Hipotesis

\begin{tabular}{|l|c|c|c|c|}
\hline & Estimate & SE & P & Keterangan \\
\hline $\begin{array}{l}\mathrm{CI} \leftarrow \\
\mathrm{PE}\end{array}$ & 0,180 & 0,104 & 0,008 & Diterima \\
\hline $\mathrm{CI} \leftarrow$ & 0,668 & 0,108 & $* * *$ & Diterima \\
$\mathrm{EE}$ & & & & \\
\hline $\begin{array}{l}\mathrm{CI} \leftarrow \\
\mathrm{SI}\end{array}$ & 0,458 & 0,810 & $* * *$ & Diterima \\
\hline $\begin{array}{l}\mathrm{CI} \leftarrow \\
\mathrm{TR}\end{array}$ & 0,014 & 0,750 & 0,848 & Ditolak \\
\hline
\end{tabular}

Mayoritas responden dalam penelitian ini jika dilihat dari segi usia adalah 21-30 tahun, artinya masuk dalam generasi $\mathrm{Y}$ dan $\mathrm{Z}$, mereka sudah terbiasa dengan teknologi sehingga menganggap penggunaan aplikasi pengiriman makanan menjadi hal yang mudah. Oleh karena itu penyedia FDA harus menjamin kinerja dan kegunaan FDA yang sesuai dengan harapan pengguna dalam kondisi pandemi, memberikan layanan pemesanan dan pengiriman stabilitas yang akurat dan tepat dengan jaminan keamanan dan kualitas. Hasil ini sejalan dengan penelitian terdahulu dimana PE memainkan peran predictor penting dalam mempengaruhi CI secara positif. Yuan $d k k$. (2016) mendukung hasil yang serupa. Selain itu, temuan ini telah di validasi dalam berbagai konteks oleh penelitian masing-masing (Zhou, 2011; Lai \& Shi, 2015; Chopdar \& Sivakumar, 2019; Susanto dkk. 2013; Marinković dkk. 2020).

Mayoritas responden dalam penelitian ini adalah usia responden antara 21 sampai 30 tahun sebesar $63,8 \%$ serta pendidikan terakhir S1. Usia tersebut masuk dalam kategori generasi Y, dimana mereka sudah terbiasa dengan segala sesuatu yang berhubungan dengan teknologi, sudah terbiasa dengan penggunaan aplikasi dalam berbagai hal, dalam hal ini FDA menjadi hal yang mudah bagi mereka dalam penggunaan dan niat untuk menggunakan secara berkelanjutan pun tinggi. Hal ini didukung oleh beberapa penelitian terdahulu. (Kang, 2014; Fang \& Fang, 2016; Ray dkk. 2019). Sejalan dengan penelitian ini EE berpengaruh positif terhadap CI.

Responden dalam penelitian ini mayoritas pekerjaan adalah pelajar dan pegawai swasta artinya bahwa sering berinteraksi sosial dengan banyak orang terdekat,. Hal ini yang membuat pengaruh sosial terhadap niat untuk terus menggunakan aplikasi pengiriman makanan pun meningkat. Demikian pula, SI juga telah di validasi sebagai penentu CI, yang secara efisien UTAUT untuk menjelaskan niat penggunaan berkelanjutan menggunakan FDA, yang didukung oleh studi sebelumnya dalam berbagai konteks adopsi teknologi masing-masing (Roh \& Park, 2019; Zhou \& Li, 2014; Lai \& Shi, 2015; Wu dkk. 2011). Mengenai peran penting SI, penyedia FDA dan perusahaan makanan perlu menciptakan pemasaran yang tepat melalui jejaring sosial. Pemasaran sosial harus diterapkan untuk mempromosikan manfaat FDA terkait dengan situasi pandemi untuk membangun reputasi FDA yang andal untuk meningkatkan niat penggunaan berkelanjutan.

Namun pengaruh TR tidak berpengaruh kuat terhadap CI. Mayoritas responden dalam frekuensi penggunaan aplikasi pengiriman makanan adalah 1 kali dalam seminggu, hal ini menunjukkan bahwa mereka sering sekali menggunakan aplikasi pengiriman makanan sehingga kepercayaan sudah bukan faktor yang mempengaruhi mereka lagi. Hasil ini bertentangan dengan temuan sebelumnya (Fang \& Fang, 2016; Marinković dkk. 2020; Zhao \& Bacao, 2020), tetapi konsisten dengan hasil dari (Yuan dkk., 2016; Chopdar \& Sivakumar, 2019). Karena pengguna memperoleh pengalaman yang cukup dari penggunaan FDA sebelumnya, pengenalan dan keakraban FDA akan meningkat dengan pengalaman penggunaan mereka. Oleh karena itu, kepercayaan pengguna tidak akan lagi 
menentukan niat berkelanjutan pengguna setelah adopsi awal FDA. Sementara itu selama pandemi COVID-19, fitur FDA lainnya, seperti, keamanan, keandalan dan efisiensi sebagai penentu yang lebih penting dapat memberikan lebih banyak manfaat bagi pengguna, yang secara lebih langsung mempengaruhi niat penggunaan berkelanjutan.

\section{KESIMPULAN}

Hasil penelitian menunjukkan niat pelanggan untuk terus menggunakan FDA selama pandemi COVID-19 dipengaruhi oleh performance, effort, social influence. Artinya bahwa semakin mudah menggunakan aplikasi dan tampilan yang nyaman dari aplikasi pengiriman makanan maka akan meningkatkan niat secara berkelanjutan terhadap aplikasi pengiriman makanan. Social influence berpengaruh terhadap continuance intention FDA artinya semakin besar pengaruh sosial untuk menggunakan aplikasi pengiriman makanan maka niat untuk terus menggunakan FDA akan tinggi. Peran sosial begitu besar terhadap keputusan seseorang untuk melakukan atau tidak melakukan sesuatu. Trust dalam penelitian ini tidak memiliki pengaruh yang kuat terhadap continuance intention FDA selama masa pandemi COVID-19.

\section{SARAN}

Penelitian dan pemangku kepentingan yang relevan harus menggabungkan fitur teknologi tertentu dengan persepsi teknologi dan mental pengguna untuk menganalisis dan memahami perilaku pengguna dan niat melanjutkan dalam situasi tertentu secara integral.

Ada tiga keterbatasan utama dari penelitian ini dan memberikan rekomendasi yang relevan untuk penelitian selanjutnya. Pertama, penelitian ini berfokus pada pengguna FDA di Indonesia, dan hasil penelitian ini mungkin tidak dapat di generalisasikan untuk budaya, wilayah, dan negara yang berbeda. Oleh karena itu, penelitian selanjutnya disarankan untuk memperhatikan daerah atau negara yang berbeda. Selain itu, perbandingan lintas budaya juga sangat dianjurkan. Kedua, penelitian ini hanya melakukan refleksi jangka pendek dari persepsi pengguna terhadap niat penggunaan berkelanjutan FDA, terutama dalam situasi tertentu (konteks pandemi COVID-19). Menurut dinamika spasial temporal dari perilaku dan niat individu, penelitian masa depan dapat menerapkan metode longitudinal dan eksperimental untuk mengeksplorasi persepsi pengguna dalam situasi yang berbeda dan menyelidiki kausalitas dari waktu ke waktu dan membuat perbandingan, untuk menjelaskan secara lebih komprehensif niat penggunaan berkelanjutan pengguna teknologi. Ketiga, penelitian saat ini tidak membedakan platform FDA yang berbeda seperti Gojek, Grab, dan lain sebagainya. Sementara itu, penelitian ini hanya berfokus pada perspektif pelanggan terhadap FDA. Akibatnya, model penelitian dapat di generalisasi untuk diterapkan pada perbedaan platform FDA yang berbeda, pemangku kepentingan yang berbeda, misalnya pemilik bisnis, penyedia layanan, dan konteks lain dari industri layanan online ke offline.

\section{DAFTAR PUSTAKA}

Cho, M., Bonn, M. A. and Li, J. (Justin) (2019) 'Differences in perceptions about food delivery apps between single-person and multi-person households', International Journal of Hospitality Management. Elsevier, 77(February), pp. 108-116. doi: 10.1016/j.ijhm.2018.06.019.

Chong, A. Y. L. (2013) 'Understanding mobile commerce continuance intentions: An empirical analysis of chinese consumers', Journal of Computer Information Systems, 53(4), pp. 22-30. doi: 10.1080/08874417.2013.11645647.

Chopdar, P. K. and Sivakumar, V. J. (2019) 'Understanding continuance usage of mobile shopping applications in India: the role of espoused cultural values and perceived risk', Behaviour and Information Technology. Taylor \& Francis, 38(1), pp. 42-64. doi: 10.1080/0144929X.2018.1513563.

Elvandari, C. D. R., Sukartiko, A. C. and Nugrahini, A. D. (2018) 'Identification of Technical Requirement for Improving Quality of Local Online Food Delivery Service in Yogyakarta', Journal of Industrial and Information Technology in Agriculture, 1(2), p. 1. doi: 10.24198/jiita.v1i2.14573.

Fang, I. C. and Fang, S. C. (2016) 'Factors affecting consumer stickiness to continue using mobile applications', International Journal of Mobile Communications, 14(5), pp. 431-453. doi: 10.1504/IJMC.2016.078720.

Gao, L., Waechter, K. A. and Bai, X. (2015) 'Understanding consumers' continuance intention towards mobile purchase: A theoretical framework and empirical study - A case of China', Computers in Human Behavior. Elsevier Ltd, 53, pp. 249-262. doi: 10.1016/j.chb.2015.07.014.

Hair, J. F. dkk. (2010) Multivariate Data Analysis. 7th ed. New Jersey: Pearson Prentice Hall.

Hair, J. F. dkk. (2019) 'When to Use and How to Report The Results of PLS-SEM', European Business Review, 31(1), pp. 2-24. doi: 10.1108/EBR-11-20180203.

Israel, D. J. and Velu, R. (2019) 'Consumer's intention to continuous use of mobile food delivery aggregator app', Journal of Advanced Research in Dynamical and Control Systems, 11(7), pp. 119-128.

Kang, S. (2014) 'Factors influencing intention of mobile application use', International Journal of Mobile Communications, 12(4), pp. 360-379. doi: 10.1504/IJMC.2014.063653.

Lai, I. K. W. and Shi, G. (2015) 'The impact of privacy concerns on the intention for continued use of an integrated mobile instant messaging and social network platform', International Journal of Mobile 
Communications, 13(6), pp. 641-669. doi: 10.1504/IJMC.2015.072086.

Liu, S. and Wang, J. (2016) The Internet Society in China, The Internet Society in China. Beijing China: China Renmin University Press. doi: 10.1007/978981-13-8237-6.

Marinković, V., Đorđević, A. and Kalinić, Z. (2020) 'The moderating effects of gender on customer satisfaction and continuance intention in mobile commerce: a UTAUT-based perspective', Technology Analysis and Strategic Management. Taylor \& Francis, 32(3), pp. 306-318. doi: 10.1080/09537325.2019.1655537.

Mun, Y. P., Khalid, H. and Nadarajah, D. (2017) 'Millennials' Perception on Mobile Payment Services in Malaysia', Procedia Computer Science. Elsevier B.V., 124, pp. 397-404. doi: 10.1016/j.procs.2017.12.170.

Ray, A. dkk. (2019) 'Why do people use food delivery apps (FDA)? A uses and gratification theory perspective', Journal of Retailing and Consumer Services. Elsevier Ltd, 51(March), pp. 221-230. doi: 10.1016/j.jretconser.2019.05.025.

Roh, M. and Park, K. (2019) 'Adoption of O2O food delivery services in South Korea: The moderating role of moral obligation in meal preparation', International Journal of Information Management. Elsevier, 47(September 2017), pp. 262-273. doi: 10.1016/j.ijinfomgt.2018.09.017.

Sarstedt, M., Ringle, C. M. and Hair, J. F. (2017) Partial Least Squares Structural Equation Modeling, Handbook of Market Research. doi: 10.1007/978-3319-05542-8.

Shao, Z. dkk. (2019) 'Antecedents of trust and continuance intention in mobile payment platforms: The moderating effect of gender', Electronic Commerce Research and Applications. Elsevier B.V., 33, p. 100823. doi: 10.1016/j.elerap.2018.100823.

Smith, W. and Freedman (2020) 'Isolation, quarantine, social distancing and community containment: pivotal role for old- style public health measures in the novel coronavirus (2019-nCoV) outbreak', Journal of travel medicine, 27(2), p. taaa020.

Susanto, A. dkk. (2013) 'User acceptance of Internet banking in Indonesia: Initial trust formation', Information Development, 29(4), pp. 309-322. doi: $10.1177 / 0266666912467449$.

Venkatesh, V. dkk. (2011) 'Extending the two-stage information systems continuance model: Incorporating UTAUT predictors and the role of context', Information Systems Journal, 21(6), pp. 527-555. doi: 10.1111/j.1365-2575.2011.00373.x.

Wu, P. C. S., Yeh, G. Y. Y. and Hsiao, C. R. (2011) 'The effect of store image and service quality on brand image and purchase intention for private label brands', Australasian Marketing Journal. Australian and New Zealand Marketing Academy., 19(1), pp. 30-39. doi: 10.1016/j.ausmj.2010.11.001.
Yeo, V. C. S., Goh, S. K. and Rezaei, S. (2017) 'Consumer experiences, attitude and behavioral intention toward online food delivery (OFD) services', Journal of Retailing and Consumer Services. Elsevier, 35(December 2016), pp. 150-162. doi: 10.1016/j.jretconser.2016.12.013.

Yuan, S. dkk. (2016) 'An investigation of users' continuance intention towards mobile banking in China', Information Development, 32(1), pp. 20-34. doi: 10.1177/0266666914522140.

Zhao, Y. and Bacao, F. (2020) 'What factors determining customer continuingly using food delivery apps during 2019 novel coronavirus pandemic period?', International Journal of Hospitality Management. Elsevier Ltd, 91(March), p. 102683. doi: 10.1016/j.ijhm.2020.102683.

Zhou, T. (2011) 'Examining the critical success factors of mobile website adoption', Online Information Review, 35(4), pp. 636-652. doi: $10.1108 / 14684521111161972$.

Zhou, T. and Li, H. (2014) 'Understanding mobile SNS continuance usage in China from the perspectives of social influence and privacy concern', Computers in Human Behavior. Elsevier Ltd, 37, pp. 283-289. doi: 10.1016/j.chb.2014.05.008. 